\title{
Influence of drip fertigation on nutrient uptake and nutrient use efficiency of aerobic paddy
}

\section{R. KRISHNA MURTHY AND K. PUSHPA}

Received : 23.07.2015; Revised : 03.11.2015; Accepted : 18.11.2015

MEMBERS OF RESEARCH FORUM:
Corresponding author :
R. KRISHNA MURTHY, Soil and Water
Management, Zonal Agricultural
Research Station, V.C. Farm,
MANDYA (KARNATAKA) INDIA
Email: srkmurthyssac@gmail.com

Co-authors :

K. PUSHPA, Soil and Water

Management, Zonal Agricultural

Research Station, V.C. Farm,

MANDYA (KARNATAKA) INDIA

\section{Summary}

A field experiment was conducted during Kharif 2014 to study the influence of drip fertigation on nutrient uptake and nutrient use efficiency of aerobic rice at Zonal Agricultural Research Station, V.C. Farm, Mandya. Significantly higher total nitrogen, phosphorus and potassium uptake was recorded with irrigation @ 150 per cent CPE + DF 125 per cent $\operatorname{RDF}(105.77,42.66$ and $92.02 \mathrm{~kg} \mathrm{ha}^{-1}$, respectively), as compared to irrigation @ 100 per cent CPE + DF 75 per cent RDF (45.9, 16.85 and $26.51 \mathrm{~kg} \mathrm{ha}^{-1}$, respectively). Similarly significantly higher total calcium, magnesium and sulphur uptake was registered with irrigation @ 150 per cent CPE + DF 125 per cent $\left(62.34,41.33\right.$ and $23.03 \mathrm{~kg} \mathrm{ha}^{-1}$, respectively). Significantly higher total manganese, iron, zinc, copper and boron uptake was registered with irrigation @ 150 per cent CPE + DF 125 per cent $\left(91.13,425.06,124.46,45.36\right.$ and $33.49 \mathrm{~g} \mathrm{ha}^{-1}$, respectively) and further it was followed by irrigation@125 per cent CPE + DF 125 per cent RDF $(84.93,397.63,12.03,42.6$ and $33.49 \mathrm{~g}$ ha ${ }^{1}$, respectively) and lowest uptake was noticed with irrigation @ 100 per cent CPE + DF 75 per cent RDF. Irrigation @ 150 per cent CPE and 75 per cent RDF through drip fertigation recorded non significantly higher N, P and K use efficiency $\left(58.11,116.54\right.$ and $116.5 \mathrm{~kg} \mathrm{~kg}^{-1}$, of NPK, respectively) and further followed by irrigation @ 125 per cent CPE + DF 75 per cent RDF $\left(48.69,97.13\right.$ and $97.13 \mathrm{~kg} \mathrm{~kg}^{-1}$, of NPK, respectively).

Key words : Drip, Fertigation, Cumulative pan evaporation, Soil moisture

How to cite this article : Murthy, R. Krishna and Pushpa, K. (2015). Influence of drip fertigation on nutrient uptake and nutrient use efficiency of aerobic paddy. Asian J. Soil Sci., 10(2) : 266-270. 